\title{
FOUR CROPS BASED CROPPING PATTERN STUDIES FOR INCREASING CROPPING INTENSITY AND PRODUCTIVITY IN RAJSHAHI REGION OF BANGLADESH
}

\author{
I. Hossain ${ }^{1}$, M. R. I. Mondal2 ${ }^{2}$, M. J. Islam³, M. A. Aziz ${ }^{4}$, A. S. M. M. R. Khan ${ }^{5}$ and F. Begum ${ }^{6}$ \\ ${ }^{1}$ Senior Scientific Officer, ${ }^{3}$ Scientific Officer, Regional Wheat Research Centre, BARI, Rajshahi \\ ${ }^{2}$ Director General, ${ }^{4}$ Chief Scientific Officer, ${ }^{5}$ Principal Scientific Officer, ${ }^{6}$ Principal Scientific Officer, \\ Bangladesh Agricultural Research Institute, Joydebpur, Gazipur \\ Corresponding author: iliasrwrc@gmail.com
}

Key words: Four crops, cropping intensity, productivity, rice equivalent yield

\begin{abstract}
A field trial was conducted at the Regional Wheat Research Centre of Bangladesh Agricultural Research Institute (BARI), Rajshahi to study the comparative agronomic performance and economic return of four crops based cropping patterns. The cropping patterns were as follows: $\mathrm{CP}_{1}=$ Transplanted Aman rice (cv. Binadhan-7)-Mustard (cv. BARI Sarisha14)-Boro rice (cv. BRRI dhan28) - Transplanted Aus rice (cv. Parija); $\mathrm{CP}_{2}=$ T. Aman rice-Potato (cv. Diamont)-Boro rice-T.Aus rice; $\mathrm{CP}_{3}=\mathrm{T}$. Aman rice-Mustard (cv. BARI Sarisha15)-Mungbean (cv. BARI Mung 6) $-\mathrm{T}$. Aus rice and $\mathrm{CP}_{4}=\mathrm{T}$. Aman rice-Fallow-Boro rice-Fallow (Control). The results showed that four crops could be grown successfully one after another in a sequence in the field with three crops patterns. The highest rice equivalent yield (REY) $25.62 \mathrm{t} \mathrm{ha}^{-1}$ was obtained from the cropping pattern $\mathrm{CP}_{2}$ (T. Aman rice-Potato-Boro rice-T.Aus rice) and it was followed by $\mathrm{CP}_{1}$ (18.49) and $\mathrm{CP}_{3}$ (16.03) during one year crops cycle. The highest gross margin Tk. 148882 ha $^{-1}$ was also obtained from $\mathrm{CP}_{2}$ followed by $\mathrm{CP}_{3}$ (Tk. $133315 \mathrm{ha}^{-1}$ ). The highest MBCR (2.24) was however, obtained from the cropping pattern $\mathrm{CP}_{3}$ (T. AmanMustard-Mungbean-T. Aus). Based on overall yield performance, economic benefit and climatic situation of Rajshahi region it may be concluded that $\mathrm{CP}_{3}$ was the best pattern than others.
\end{abstract}

\section{Introduction}

Bangladesh is a densely populated (1008 per sq. km.) country with an area of 1,47, 570 sq.km and population of about 149 million with an increasing rate of $1.37 \%$ per year (BBS, 2011). At present total cultivable land is 8.5 million hectare which is decreasing at the rate of about $1 \%$ per year. There is very little scope for increasing cultivated land though there is an ample scope for increasing cropping intensity from the present $190 \%$ to $400 \%$, by incorporating short duration crops, like mustard, potato, mungbean and aus rice in the rice based cropping patterns. Sustainable crop production in Bangladesh through improvement of cropping pattern in rice based cropping system is regarded as increasingly important in national issues such as food security, poverty alleviation and creation of job opportunity (Aziz and Rahman, 2011). The main challenge of the new millennium is to increase per unit yield by at least $50 \%$ through manipulating the limited land resource. In this regard, the challenges for the agronomists are to understand crop production problems and processes to develop the best ways of production technologies for the management of problems and sustainable production. In case of production agronomy, targeting high yield through high cropping intensity and productivity is the most logical way to raise the total production. However, in order to produce more food within a limited area, two most important options to be adopted are i) to increase the cropping intensity 
Hossain et al.

by producing three or more crops over the same piece of land in a year, and ii) to increase the production efficiency of the individual crop by using optimum management practices.

Oilseeds and pulses are the important group of crops which are mostly grown in rabi (winter) season in Bangladesh. The areas of oilseeds and pulses in rabi season are decreasing because of increasing cultivation of irrigated boro rice (Wahhab et al., 2002). Recently, with the development of short duration rice, crops like mustard, potato and pulses can be accommodated in four crops based cropping pattern in a same piece of land in a year. Rapeseed-mustard production can be increased by $20-25 \%$ only replacing traditional variety by high yielding short duration ones, like BARI Sarisha-14 and BARI Sarisha-15 in the existing rice based cropping system (Elias et al., 1986). Pulses are inherently important grain legume crops in Bangladesh for their importance as food, feed and in soil improvement process ( Mondal et al., 2011). They are generally grown without or little fertilizers since they can meet a major portion of their nitrogen requirement by symbiotic fixation of atmospheric nitrogen in the soil (Islam, 1991). Nevertheless, pulses supply a substantial amount of nitrogen to the succeeding non-legume crops grown in rice based cropping system (Rachie and Roberts, 1974; Ahlawat et al., 1981; Kurtz et al., 1984; Sharma and Prasad, 1999).

Undoubtedly, potential adoption of mustard, mungbean and potato in T. aman-Fallow-BoroFallow cropping system would increase crop productivity, generate employment and bring additional income for the rural poor by utilizing fallow and under-used lands of the country. However, the benefit of incorporation of extra crops in the rice based cropping pattern will largely depends on the selection of suitable crop varieties and adoption of appropriate agronomic practices. The present experiment was therefore, undertaken to study the economic feasibility of growing four crops in a year in a piece of land by incorporating mustard, potato, mungbean and aus rice in the existing two or three crops based pattern.

\section{Materials and Methods}

The field experiment was conducted at the Regional Wheat Research Centre (WRC) of Bangladesh Agricultural Research Institute (BARI), Rajshahi (AEZ 11) during 2012-2013 (July 2012 through June 2013). Soil analysis report of the field is presented in Table 1. Four cropping patterns were as follows:

$\mathrm{CP}_{1}=\mathrm{T}$. Aman - Mustard - Boro $-\mathrm{T}$. Aus

$\mathrm{CP}_{2}=\mathrm{T}$. Aman - Potato - Boro $-\mathrm{T}$. Aus

$\mathrm{CP}_{3}=\mathrm{T}$. Aman - Mustard - Mungbean $-\mathrm{T}$. Aus

$\mathrm{CP}_{4}=\mathrm{T}$. Aman - Fallow - Boro - Fallow (control)

Table 1. Initial soil properties of the experimental field of RWRC, BARI, Rajshahi during 2012-13

\begin{tabular}{|c|c|c|c|c|c|c|c|c|}
\hline \multirow[t]{2}{*}{ Sample } & \multirow[t]{2}{*}{$\mathrm{pH}$} & \multirow[t]{2}{*}{ OM (\%) } & \multirow{2}{*}{$\begin{array}{l}\text { Total } \\
\mathrm{N}(\%) \\
\end{array}$} & $\mathrm{K}$ & $\mathrm{P}$ & $\mathrm{S}$ & $\mathrm{Zn}$ & $\mathrm{B}$ \\
\hline & & & & meq. 10 & -1 soil & \multicolumn{3}{|c|}{$\mathrm{g} \mathrm{g}^{-1}$ soil } \\
\hline Value & 7.8 & 0.74 & 0.05 & 0.21 & 10 & 23.3 & 0.14 & 0.27 \\
\hline Critical level & - & - & 0.12 & 0.12 & 10 & 10.0 & 0.60 & 0.20 \\
\hline Interpretation & $\begin{array}{l}\text { Slightly } \\
\text { Alkaline }\end{array}$ & $\begin{array}{l}\text { Very } \\
\text { low }\end{array}$ & $\begin{array}{l}\text { Very } \\
\text { low }\end{array}$ & Medium & Low & Optimum & $\begin{array}{l}\text { Very } \\
\text { low }\end{array}$ & $\begin{array}{l}\text { Very } \\
\text { low }\end{array}$ \\
\hline
\end{tabular}

The experiment was laid out in a Randomized Complete Block (RCB) design with 4 replications. The unit plot size was $6 \mathrm{~m} \times 4 \mathrm{~m}$. Transplanted aman (T.aman) rice was grown during the Kharif II 
Four Crops Based Cropping Pattern

season and it was the first crop of the sequence. Fertilizers management and intercultural operations like weeding, mulching etc. were done according to Rahman et al. (2008). Seedlings were grown in seedbed in a separate plot. 25 days old seedling of Binadhan 7 was transplanted with $20 \mathrm{~cm}$ x $15 \mathrm{~cm}$ spacing on 20 July, 2012. T.aman rice was harvested on 21 October, 2012. Rice was harvested at $30 \mathrm{~cm}$ height from soil surface and remaining part of the rice plant was incorporated with soil. Grain and straw yields were taken from whole plot. As per treatment potato was grown during Rabi season. Fertilizers management and intercultural operations like weeding, mulching etc. were done according to Kabir and Haque (2012). Potato tubers (cv. Diamont) were planted with $60 \mathrm{~cm} \times 25 \mathrm{~cm}$ spacing on 25 October, 2012. Potato was harvested on 24 January in the same year. Tuber and foliage (over dry) weight were taken from the whole plot. Mustard was grown during Rabi season. Fertilizers management and intercultural operations like weeding, mulching etc. were done according to Mondal and Wahhab (2001). BARI Sarisha-14 and BARI Sarisha-15 were planted with $30 \mathrm{~cm} \times 5 \mathrm{~cm}$ spacing on 25 October, 2012. BARI Sarisha-14 was harvested on 20 January, 2013 while BARI Sarisha-15 was harvested on 24 January, 2013. Seed yield and straw yield were taken from the whole plot.

Mungbean was grown during Kharif-I season. Fertilizers management and intercultural operations were done according to Afzal et al. (2008). Mungbean (cv. BARI mung-6) was sown on 05 February, 2013. Mungbean was harvested on 15 April, 2013. Seed yield and biomass weight of mungbean were taken from the entire plot. After harvesting of pods, mungbean plants were incorporated into the soil. Boro was the third crop of the sequence. Fertilizers management and intercultural operations were done according to Haque et al. (2011). Thirty five days old seedlings of BRRI dhan28 were transplanted with $20 \mathrm{~cm} \times 15 \mathrm{~cm}$ spacing on 15 January, 2013 in $\mathrm{CP}_{4}$; 27 January, 2013 in $\mathrm{CP}_{1}$ and 27 January, 2013 in $\mathrm{CP}_{2}$. Boro rice was harvested on 12 May, 12 May \& 10 May, 2013 in $\mathrm{CP}_{1}, \mathrm{CP}_{2}$ and $\mathrm{CP}_{4}$, respectively Rice was harvested at $30 \mathrm{~cm}$ height from soil surface and the remaining part of the rice plant was incorporated with soil. Grain yield and straw yield were taken from the whole plot. Transplanted aus (T.aus) rice was the fourth crop of the sequence. Fertilizers management and intercultural operations like weeding, mulching, etc. were done according to Haque et al. (2011). Twenty-day aged seedlings of Parija were transplanted with $15 \mathrm{~cm} \times 15 \mathrm{~cm}$ spacing on 15 May both in $\mathrm{CP}_{1}$ and $\mathrm{CP}_{2}$ and on 20 April in $\mathrm{CP}_{3}$ in the same year. $\mathrm{T}$. aus was harvested on 24 July in $\mathrm{CP}_{1} ; 23$ July in $\mathrm{CP}_{2}$ and 7 July in $\mathrm{CP}_{3}$. Rice was harvested at $30 \mathrm{~cm}$ height from soil surface and remaining part of the rice plant was incorporated with soil. Grain yield and straw yield were taken from whole plot.

\section{Statistical analysis of data}

MSTAT-C and Microsoft Excel and DMRT were used to measure the variation of mean data of treatments. Treatment means were compared at $\mathrm{P} \leq 0.05$. The data were analyzed statistically following computer package MSTATC. All the data were statistically analyzed following the ANOVA technique and the significance of mean differences was adjusted by Duncan's Multiple Range Test

\section{Results and Discussions}

Results from Table 2 revealed that grain and straw yields of $\mathrm{T}$. aman rice were $4.53 \& 515 \mathrm{t}$ $\mathrm{ha}^{-1}$, grain and straw yields of mustard (BARI Sarisha-14) were $1.46 \mathrm{t} \mathrm{ha}^{-1} \& 3.12 \mathrm{t} \mathrm{ha}^{-1}$, grain and straw yields of Boro rice were $6.10 \& 7.14 \mathrm{t} \mathrm{ha}^{-1}$ and grain and straw yields of $\mathrm{T}$. aus were $3.85 \& 4.45 \mathrm{t} \mathrm{ha}^{-1}$, respectively in case of cropping pattern 1 . In case of cropping pattern 2 , 
Hossain et al.

grain and straw yields of $\mathrm{T}$. aman were $4.09 \mathrm{t} \mathrm{ha}^{-1} \& 4.72 \mathrm{t} \mathrm{ha} \mathrm{a}^{-1}$, tuber yield of potato was $19.58 \mathrm{t} \mathrm{ha}^{-1}$ and straw yield was $2.12 \mathrm{t} \mathrm{ha}^{-1}$, grain and straw yields of Boro rice were $5.85 \&$ $6.58 \mathrm{t} \mathrm{ha}^{-1}$ and grain and straw of $\mathrm{T}$. aus rice were $3.92 \mathrm{t} \mathrm{ha}^{-1} \& 4.54 \mathrm{t} \mathrm{ha}^{-1}$, respectively. In case of cropping pattern 3 , grain and straw yields of $T$. aman rice were $4.43 \& 5.11 \mathrm{t} \mathrm{ha}^{-1}$, grain and straw yields of mustard (BARI Sarisha-15) were $1.48 \& 3.07 \mathrm{t} \mathrm{ha}^{-1}$, seed and straw yields of mungbean were $0.664 \mathrm{t} \mathrm{ha}^{-1} \& 2.21 \mathrm{t} \mathrm{ha}^{-1}$ and grain and straw yields of $\mathrm{T}$. aus rice were $3.85 \&$ $4.49 \mathrm{t} \mathrm{ha}^{-1}$, respectively. Whereas, in case of cropping pattern 4 grain and straw yields of $\mathrm{T}$. aman were $4.78 \& 5.48 \mathrm{t} \mathrm{ha}^{-1}$ and grain and straw yields of Boro rice were $7.50 \& 8.21 \mathrm{t} \mathrm{ha}^{-1}$, respectively.

Table 2. Performance of different crops under four cropping patterns during 2012-13 at RWRC, BARI, Rajshahi

\begin{tabular}{|c|c|c|c|c|c|c|c|c|}
\hline \multirow[t]{2}{*}{ Crop } & \multicolumn{4}{|c|}{ Copping pattern 1} & \multicolumn{4}{|c|}{ Copping pattern 2} \\
\hline & T.aman & Mustard & Boro & T.aus & T.aman & Potato & Boro & T.aus \\
\hline Variety & Binadhan 7 & $\begin{array}{c}\text { BARI } \\
\text { Sarisha-14 }\end{array}$ & $\begin{array}{c}\text { BRRI } \\
\text { dhan28 }\end{array}$ & Parija & Binadhan 7 & Diamont & $\begin{array}{c}\text { BRRI } \\
\text { dhan28 }\end{array}$ & Parija \\
\hline $\begin{array}{l}\text { Sowing/ } \\
\text { Transplanti } \\
\text { no date }\end{array}$ & $20 / 7 / 12$ & $25 / 10 / 12$ & $27 / 1 / 13$ & $15 / 5 / 13$ & $20 / 7 / 12$ & $25 / 10 / 12$ & $27 / 1 / 13$ & $15 / 5 / 13$ \\
\hline $\begin{array}{l}\text { ng date } \\
\text { Crop } \\
\text { duration }\end{array}$ & 91 & 83 & 102 & 70 & 91 & 89 & 103 & 69 \\
\hline $\begin{array}{l}\text { Harvesting } \\
\text { date }\end{array}$ & $21 / 10 / 12$ & $24 / 1 / 13$ & $12 / 5 / 13$ & $24 / 7 / 13$ & $21 / 10 / 12$ & $24 / 1 / 13$ & $12 / 5 / 13$ & $23 / 7 / 13$ \\
\hline $\begin{array}{l}\text { Grain Yield } \\
\left(\mathrm{t} \mathrm{ha}^{-1}\right)\end{array}$ & 4.53 & 1.46 & 6.10 & 3.85 & 4.09 & 19.58 & 5.87 & 3.92 \\
\hline $\begin{array}{l}\text { Straw yield } \\
\left(\mathrm{t} \mathrm{ha}^{-1}\right)\end{array}$ & 5.15 & 3.12 & 7.14 & 4.45 & 4.72 & 2.12 & 6.58 & 4.54 \\
\hline REY & 4.53 & 5.35 & 5.08 & 3.53 & 4.09 & 13.05 & 4.89 & 3.59 \\
\hline $\operatorname{LSD}_{(0.05)}$ & 0.12 & 0.082 & 0.132 & 0.122 & 0.054 & 0.465 & 0.121 & 0.121 \\
\hline $\mathrm{CV}(\%)$ & 7.16 & 4.55 & 6.54 & 7.21 & 8.12 & 4.15 & 6.15 & 4.55 \\
\hline
\end{tabular}

Continuation

\begin{tabular}{|c|c|c|c|c|c|c|c|c|}
\hline \multirow[t]{2}{*}{ Crop } & \multicolumn{4}{|c|}{ Copping pattern 3} & \multicolumn{4}{|c|}{ Copping pattern 4} \\
\hline & T.aman & Mustard & $\begin{array}{c}\text { Mung } \\
\text { bean }\end{array}$ & T.aus & T.aman & Fallow & Boro & Fallow \\
\hline Variety & Binadhan 7 & $\begin{array}{c}\text { BARI } \\
\text { Sarisha-15 }\end{array}$ & $\begin{array}{c}\text { BARI } \\
\text { Mung-6 }\end{array}$ & Parija & Binadhan 7 & $\begin{array}{ll}- & - \\
\end{array}$ & $\begin{array}{c}\text { BRRI } \\
\text { dhan } 28\end{array}$ & - \\
\hline $\begin{array}{l}\text { Sowing/ } \\
\text { Transplanti } \\
\text { ng date }\end{array}$ & $20 / 7 / 12$ & $25 / 10 / 12$ & $5 / 2 / 13$ & $20 / 4 / 13$ & $20 / 7 / 12$ & - & $\begin{array}{c}15 / 1 / 1 \\
3\end{array}$ & - \\
\hline $\begin{array}{l}\text { Crop } \\
\text { duration }\end{array}$ & 91 & 85 & 71 & 72 & 94 & - & 116 & - \\
\hline $\begin{array}{l}\text { Harvesting } \\
\text { date }\end{array}$ & $21 / 10 / 12$ & $20 / 1 / 13$ & $15 / 4 / 13$ & 7/7/13 & $21 / 10 / 12$ & - & $\begin{array}{c}10 / 5 / 1 \\
3\end{array}$ & - \\
\hline $\begin{array}{l}\text { Grain Yield } \\
\text { (t/ha) }\end{array}$ & 4.43 & 1.48 & 0.664 & 3.85 & 4.78 & - & 7.50 & - \\
\hline $\begin{array}{l}\text { Straw yield } \\
\text { (t/ha) }\end{array}$ & 5.11 & 3.07 & 2.21 & 4.49 & 5.48 & - & 8.21 & - \\
\hline REY & 4.43 & 5.42 & 2.65 & 3.53 & 4.78 & - & 6.25 & - \\
\hline $\operatorname{LSD}_{(0.05)}$ & 0.055 & 0.245 & 0.314 & 0.053 & 0.015 & & 0.215 & \\
\hline CV(\%) & 3.56 & 4.25 & 7.15 & 9.45 & 2.75 & & 4.65 & \\
\hline
\end{tabular}


Four Crops Based Cropping Pattern

Total productivity of different cropping sequences was determined by rice equivalent yield (REY) which was calculated from yield of component crops. Rice equivalent yield was different under different cropping sequence (Table 3). The highest REY $\left(25.62 \mathrm{t} \mathrm{ha}^{-1}\right)$ was recorded from the cropping sequence T. aman - Potato - Boro - T.aus, which was followed by T. aman - Mustard - Boro - T. aus (18.49 tha-1). The lowest REY (11.03 $\left.\mathrm{t} \mathrm{ha}^{-1}\right)$ was obtained from the cropping sequence $\mathrm{T}$. aman - Fallow - Boro - Fallow. Inclusion of mustard during rabi season in $\mathrm{CP}_{1}$ and $\mathrm{CP}_{3}$ increased REY 51.6 to $45.3 \%$ compared to farmer's pattern $\mathrm{CP}_{4}$. On the other hand, inclusion of potato in $\mathrm{CP}_{2}$ increased $\mathrm{REY} 132.2 \%$ during 2012-13.

\section{Economic Analysis}

Economics of system productivity of four cropping sequences showed in Table 3 revealed that the gross return was different for different cropping patterns. The highest gross return (Tk. 384300 ha $^{-1}$ ) was recorded from T. aman - potato - Boro - T. aus cropping pattern 2 followed by T. aman - Mustard - Boro - T. aus cropping pattern1 (Tk. 277350 ha $^{-1}$ ), T. aman - Mustard - Mungbean - T. aus cropping pattern 3 (Tk. 240450 ha $^{-1}$ ). T. aman - Fallow - Boro - Fallow cropping pattern 4 gave the lowest gross return (Tk. $165450 \mathrm{ha}^{-1}$ ). Total variable cost was lower in cropping pattern 3 (Tk. 107335 ha $^{-1}$ ) followed by cropping pattern4 (Tk. 110132 ha $^{-1}$ ). The highest total variable cost (Tk. 235418 ha $^{-1}$ was recorded from cropping pattern 2 and might be due to higher seed cost of potato. The highest gross margin was obtained from cropping pattern 2 (Tk. 148882 ha $^{-1}$ ) followed by cropping pattern3 (Tk. 133315 ha $^{-1}$ ), cropping pattern1 (Tk. 114915 ha- $^{-1}$ ). Cropping pattern 4 gave the lowest gross margin (Tk. $55318 \mathrm{ha}^{-1}$ ). The highest marginal benefit cost ration (MBCR) was found in cropping pattern 3 (2.24) followed by cropping pattern 1 (1.70), cropping pattern 2 (1.63). Farmer's pattern (control) $\mathrm{CP}_{4}$ gave the lowest MBCR (1.50) during one year crops period.

Table 3. Rice equivalent yield, cost and return of four cropping patterns during 2012-13 at RWRC, BARI, Rajshahi

\begin{tabular}{l|c|c|c|c|c}
\hline Pattern & $\begin{array}{c}\text { REY } \\
\left(\mathrm{t} \mathrm{ha}^{-1}\right)\end{array}$ & $\begin{array}{c}\text { Gross return } \\
\left(\text { Tk. ha }^{-1}\right)\end{array}$ & $\begin{array}{c}\text { Variable cost } \\
(\text { Tk. ha-1) }\end{array}$ & $\begin{array}{c}\text { Gross margin } \\
(\text { Tk. ha-1) }\end{array}$ & MBCR \\
\hline CP1 & 18.49 & 277350 & $162435 /-$ & $114915 /-$ & 1.70 \\
CP2 & 25.62 & 384300 & $235418 /-$ & $148882 /-$ & 1.63 \\
CP3 & 16.03 & 240450 & $107135 /-$ & $133315 /-$ & 2.24 \\
CP4 & 11.03 & 165450 & $110132 /-$ & $55318 /-$ & 1.50 \\
\hline
\end{tabular}

Price: T.aman:Tk. 15 kg-1, Mustard: Tk. 55 kg ${ }^{-1}$, Mungbean: Tk. 60 kg-1, Boro: Tk.12.5 kg-1, Potato: Tk.10 kg ${ }^{-1}$ and Aus: Tk. $13.75 \mathrm{~kg}^{-1}$

\section{Conclusion}

From the result of the study it may be concluded that four crops based three cropping patterns such as $\mathrm{CP}_{1}=$ Transplanted Aman rice (Binadhan7)-Mustard (BARI Sarisha-14) - Boro rice (BRRI dhan28) - Transplanted Aus rice (Parija); $\mathrm{CP}_{2}=\mathrm{T}$. aman rice - Potato (Diamont)- Boro rice $-\mathrm{T}$. aus rice; $\mathrm{CP}_{3}=\mathrm{T}$. aman rice - Mustard (BARI Sarisha-15) - Mungbean (BARI mung-6) $\mathrm{T}$. aus rice are agronomically feasible and economically profitable compared to the existing $\mathrm{T}$. aman - Fallow - Boro - Fallow pattern. However, $\mathrm{CP}_{3}$ was found the most profitable one. Due to growing of four crops in a year in the same piece of land cropping intensity and productivity will be increased, more employment opportunity for male and female labors will be created and at the same time due to increased production of rice, potato, mustard and mungbean the food and nutritional security will be ascertained for the farmers and the nation as a whole. 
Hossain et al.

\section{References}

Afzal, M. A., M. A. Baker, A. Hamid, M. J. Uddin and M. M. Haque. 2008. Bangladeshe Mungdaler Chash. Strengthning of Pulses \& Oilseed research programme in Bangladesh, BARI, Gazipur.

Ahlawat, I. P. S., A. Singh, and C. S. Saraf. 1981. Effect of winter legumes on nitrogen economy and productivity of succeeding cereals. Expt. Agric., 17: 57-62.

Aziz, M. A. and A. K. M. H. Rahman. 2011. Development of Alternate Cropping Pattern for Coastal Saline of Bangladesh Against Farmer Existing T. Aman- Fallow- Fallow Pattern. Annual Research Report, 2010-11. Agronomy Division. Bangladesh Agricultural Research Institute. Gazipur. pp.259-260.

BBS (Bangladesh Bureau of Statistics). 2011. Statistical Yearbook of Bangladesh. Bangladesh Bureau of Statistics, Ministry of Planning. Dhaka. Bangladesh.

Elias, S. M., M. S. Hossain, F. S. Sikder, M. J. Ahmed and M. M. R. Karim. 1986. Identification of constraints to pulse production with special reference to present farming systems. Annual Report of the Agricultural Economics Division, BARI, Joydebpur, p.1.

Haque, A. K. G. M. N., M. K. Basher., M. S. Islam and M. A. Khasem. 2011. Modern Rice Cultivation, $16^{\text {th }}$ edition. Bangladesh Rice Research Institute, Gazipur-1701.

Islam, S. 1991. Soil nutrient status affecting productivity of pulses in the major and potential pulsegrowing areas. In: Advances in Pulses Research in Bangladesh. Proceedings of the $2^{\text {nd }}$ national workshop on pulses, June 6-8, 1989, BARI, Gazipur. Published by ICRISAT, Patancheru, Andhra Pradesh 502 324, India.

Kabir K. H. and M. Z. Haque. 2012. Alu Chasher Adhunik Kolakowshal (Modern Production Technology of Potato), $1^{\text {st }}$ edition, TCRC, BARI, Gazipur, Bangladesh.

Kurtz, L. T., L. V. Boone, T. R. Peck, and R. G. Hoeft. 1984. Crop rotations for efficient nitrogen use, in Huck, R.D., ed., Nitrogen in Crop Production. pp.295-317. ASA-CSSA SSSA, Madison.

Mondal, M. R. I. and M. A. Wahhab. 2001. Production technology of oilcrops. Oilseed Research Centre, BARI, Joydebpur, Gazipur-1701.

Mondal, M. R. I., M. S. Islam, M. A. J. Bhyah and M. M. Rahman. 2011. Krishi Projukti Hatboi (Handbook on Agro-technology), $5^{\text {th }}$ edition. Bangladesh Agricultural Research Institute, Gazipur-1701.

Rachie, K. O. and L. M. Roberts. 1974. Grain legumes of the low land tropics. Adv. Agron., 26: 1132.

Rahman, M. S., M. A. Satter, N. Begum and M. R. Hyder. 2008. Unnata Krishi Projukti Porichity. Bangladesh Institute of Nuclear Agriculture, Mymensingh.

Sharma, S. N. and R. Prasad. 1999. Effects of sesbania green manuring and mungbean residue incorporation of productivity and nitrogen uptake of a rice-wheat cropping system. Bioresource Tech., 67 (2): 171-175.

Wahhab, M. A., M. R. I. Mondal, M. A. Akbar, M. S. Alam, M. U. Ahmed and F. Begam. 2002. Status of oilcrop production in Bangladesh. Oilseed Research Centre, BARI, Joydebpur, Gazipur-1701. 